\title{
On the origin of women geologists by means of social selection: German and British comparison
}

\begin{abstract}
Bayerische Staatssammlung für Paläontologie und Geologie, Funktionseinheit Geologie, Luisenstr. 37, 80333 München (Munich), Germany, martina.koelbl@iaag.geo.uni-muenchen.de
\end{abstract}

The history of geosciences has largely been interpreted as a history of male scientists; but the inclusion of their social frame into historical research makes clear how women in various roles have participated in and shaped the history of geology.

The paper illustrates this social history of women geologists with familiar graphical methods of geoscientists. It touches briefly on a long and little known prehistory, when geological knowledge was mingled with mythical and religious ideas or with craft-traditions of mining and alchemy. During the 18th century, women appeared as owners of natural history collections, some of which have become the nuclei of today's museum collections.

The beginning of geological research in a modern sense and thus the beginning of geological history occurred around 1800. In Germany, the early professionalisation of geology effectively precluded the collaboration of women, whereas a non-professional culture of natural sciences in Britain stimulated a local "Cambrian Explosion": Women appeared in great numbers as assistants to male relatives, as field geologists, collectors, taxonomists, and draughtswomen. The professionalisation in Britain during the second half of the 19th century led to the "extinction" of these early female scholars. With the opening of universities for female students the population of women geologists slowly increased again. The number of these professional female geoscientists was, and is, strongly modulated by local cultures of science and the socio-political environment.

\section{Introduction}

Science seems to have been wholly conducted by men. There have been some exceptions, such as the physicists Marie Curie and Lise Meitner, the mathematicians Sophia Kowalewskaja and Ada Lovelace, and the astronomer Mary Somerville, to name a few. But they appear as exceptions through a selective mantle of female invisibility which has descended on the history of science. This cloak appears thickest and largest in geology and other earth sciences. This view changes, however, when the historiography of science does more than present lists of "famous men" together with their major achievements, but explores the historical, social and political frame- works within which scientific ideas have developed. Then a number of notable women appear, who contributed to geology (Figure 1). To explore the influence of culture, politics and history on the number of women geologists, we do not necessarily need sociological and philosophical language but may use some of the tools, icons and interpretative models familiar to earth scientists. For the purpose of this paper the reader is invited to regard female geologists as palaeontological taxa, subject to evolutionary changes. They may thrive under favourable conditions leading to radiations; or restrictive environments may lead to stagnation or decline of the population. There may even be the equivalent of mass extinction events (Figure 2).

In the early days of geology, we are talking about absolute numbers too small to examine by proper statistical means, especially since the preservation of archive material concerning the history of geology in general, and especially for female geologists, is fragmentary. There is no systematic rule according to which archive material perished or survived. Consequently, there is no way to assess quantitatively how many female geologists existed in a given time-span, not even if we can agree on how to define a "female geologist" in times when there was no formal training, or before the word "geology" came into general use. Nevertheless, one can get an impression of a part of the history of geosciences that is usually neglected.

\section{From geological prehistory to history}

Early ideas about the genesis of rocks and the functioning of geological phenomena stemmed from a mythical approach to natural phenomena. This approach was the usual one throughout the European Middle Ages, and is wonderfully illustrated by the writings of Hildegard von Bingen about the origin and purpose of rocks and minerals.

Hildegard von Bingen (1098-1179?), as a tenth child in her family dedicated to God, entered a nunnery at the age of seven and later became its abbess. Suffering from long phases of illness and while under strict cloister discipline with long exhausting fasts, Hildegard had visions, which, from 1141 onwards, she systematically recorded. Among these mythical scriptures is the Liber simplicis medicinae, dealing with plants, animals, stones and metals and their use as medicines. Because today it is widely misused for esoteric purposes, the chapter on stones is - among non-historiansthe best known example of a medieval lapidary. Lapidaries were popular short treatises on the genesis of rocks and minerals and their supposed medical and magic qualities (Adams, 1938, Ogilvie, 1986, Kölbl-Ebert, 1998).

Although before the 18th century there was little systematic geological science or research, alongside this mythical and philosophical approach there developed a second non-scientific tradition leading to the accumulation of geology-related knowledge derived from alchemical, mining, and quarrying traditions. Handling this knowledge was a craft skill. At a time when workshops were still located in people's homes, women often worked alongside their husbands, for example in assaying, or in the processing of ores as can be deduced, e.g., from the illustrations to Georgius Agricola's De Re Metallica (1556) (see Figure 2, bottom at centre). 


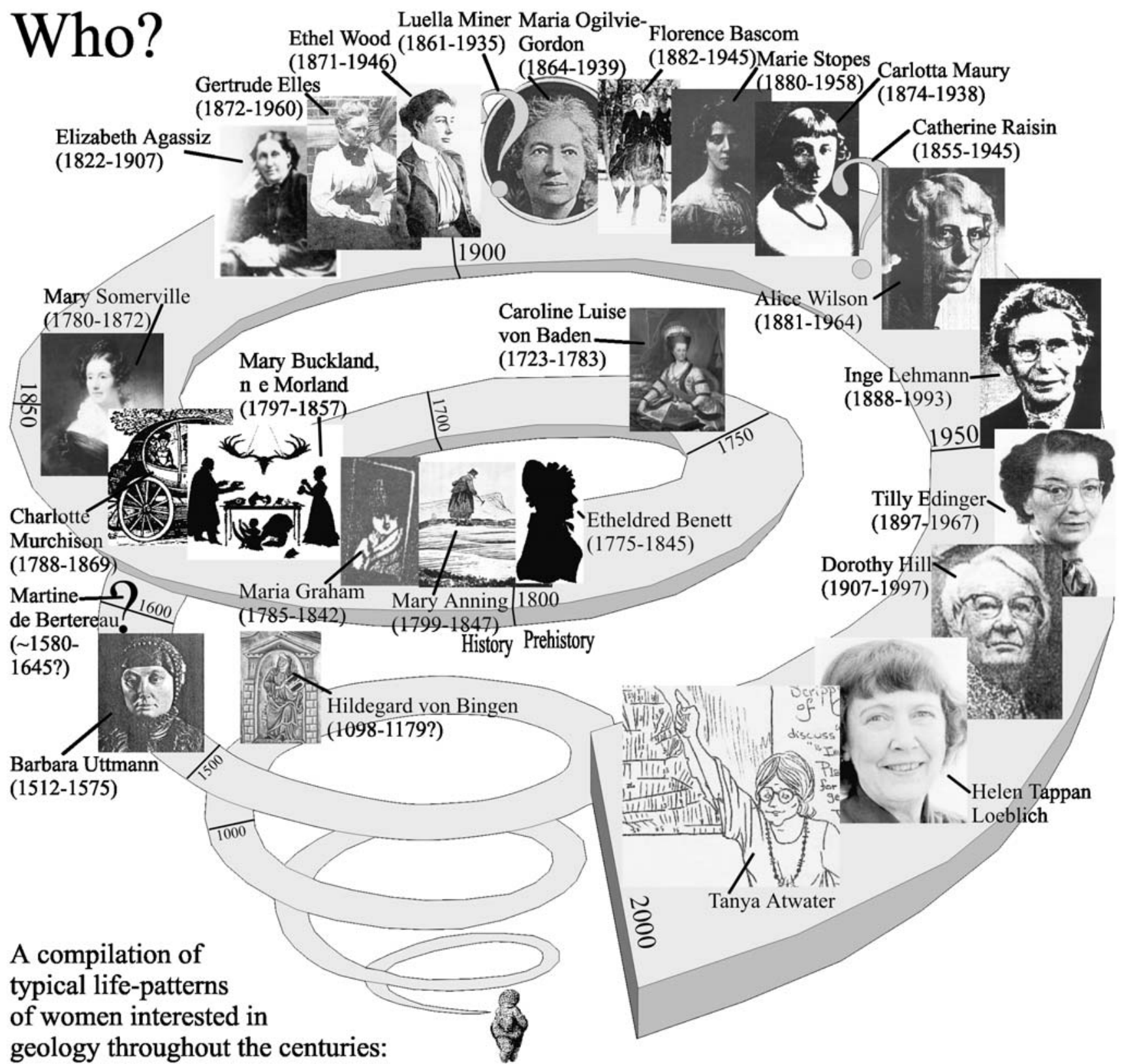

Figure 1 An arbitrary selection of women interested in geology throughout the centuries as representatives of our vast data base.

Short biographies of those women not mentioned in detail in the text of this article:

Geology's Ancestor-Mining: When Martine de Bertereau (ca. 1580-1645?) married the alchemist and mining engineer Jean du Châtelet, Baron de Beausoleil, she had "long been occupied with the art of mining that was hereditary in her family". She wrote two pamphlets on mining addressed to the French king and Cardinal Richelieu. Between 1610 and 1626, Madame de Beausoleil and her husband visited ore mines throughout Europe and probably in Peru. In France, they were commissioned to prospect for new mineral deposits and to give advice at established mines. But in 1642, they were arrested under the pretext of witchcraft. The husband died in 1645 in the Bastille, and Martine and her daughter were sent to the prison of Vincennes, where they disappeared from history. (Gobet, 1769; Herzenberg, 1986; Kölbl-Ebert, 2001)

"Seven Sisters" Side-tracking Male Universities: Elizabeth Cary Agassiz (1822-1907), second wife of Swiss-American geologist Louis Agassiz, was one of the founders of the "Harvard Annex" in 1879, a women's college whose teaching staff was initially recruited from the professors of
Harvard University. In 1894, the college received the name of "Radcliffe College". Elizabeth Agassiz served as its first President until 1899.

Radcliffe is one of the "seven sisters": seven women's colleges that opened a path to higher education for women in the US: Mount Holyoke (1837), Vassar (1865), Smith and Wellesley (1875), Radcliffe (1879), and Bryn Mawr (1885). Here women could prove their intellectual abilities as students, graduates and as lecturers. Radcliffe and Bryn Mawr quickly produced distinguished female geologists (James et al., 1971).

Missionary for Geology: Luella Miner (1861-1935), U.S. American theologian with a considerable interest in geology, went to China in 1887, where she studied Chinese. From 1903 to 1913, she established the North China Union Women's College in Beijing and assumed the position of Principal. She wrote a textbook of geology in two volumes for use in both middle and high schools, written in refined classical Chinese. Miner's Geology (1910) was the first geological textbook published in China. Luella Miner was one of twenty-six founding members of the Geological Society of China, which was established in 1922 (Xia, 1990). 
Educating the Second Generation: The US American petrologist Florence Bascom (1882-1945) was one of the pioneers when geological education at universities became available for women. She received her $\mathrm{PhD}$ degree from Johns Hopkins University in 1893 by special dispensation, since women were not admitted officially until 1907. She was appointed associate professor in geology at Ohio State University and in 1895 went to Bryn Mawr College. She also worked part-time for the USGS. As professor for geology at Bryn Mawr, she acted as teacher to numerous female geologists of the second generation (Ogilvie, 1986; Rossiter, 1982).

The Notorious Palaeobotanist - There Were More Important Issues than Geology: Marie Stopes (1880-1958) took first-class honours at University College, London and earned her doctorate in botany in 1904. She was the first female scientist on the faculty of the University of Manchester, where she lectured and researched as a palaeobotanist. She produced a catalogue of Cretaceous flora for the British Museum of Natural History.

Driven by the desolate experiences of her first marriage, she published in 1918 her best-seller Married Life, a "textbook" on human sexuality intended to ease the ignorance of her contemporaries on such matters as anatomy, fertility, birth-control and the sexual desires of men and women.

As a result of this break of social conventions she gained immediate notoriety and suffered bitter discrimination, e.g. from the Catholic Church but also from her male colleagues (Gates, 1998).

Female Globe Trotter: Carlotta Joaquina Maury (1874-1938) received her geological education at Radcliffe College (USA). She was palaeontologist to A.C. Veatch's geological expedition to Venezuela (1910-11), organized and conducted the Maury expedition to the Dominican Republic (1916), worked as consulting palaeontologist and stratigrapher for an oil company in Venezuela, and was official palaeontologist to Brazil (1914 ff.) Additionally, she was employed as lecturer and later as professor at various colleges and universities in North America and South Africa (Ogilvie, 1986).

Life-Long Struggle against Chauvinism: Alice Wilson (1881-1964) was one of the most distinguished members of the Canadian Geological Survey. Despite her fieldwork and numerous publications, promotion was denied because she had no doctorate. Her appeal for a leave of absence to acquire one was rejected for ten years, although such leaves of absence were routinely granted to men. After finally receiving half a year leave, on rather self-sacrificing conditions, she obtained the missing degree. Even then, she was not promoted, nor was her salary increased. Finally in 1940 she was promoted associate geologist and full professor in 1944 , the year before her retirement. One can assume that a shortage of young male geologists during the war was the reason (Rossiter, 1982).

Deep Inside-Deep Insight: The Danish seismologist Inge Lehmann (1888-1993), who worked for the Danish Geodetic Institute from 1925 to 1952 , suggested in 1936 , from the analysis of P-wave data, that the earth must have an inner core; an important breakthrough in the understanding of the nature of the Earth's interior. Lehmann also worked on the structure of the earth's mantle (Bolt, 1987).

Among these women was a notable business woman, Barbara Uttmann (1512-1575), a relative of Agricola and pupil of Adam Riese, who lived in Annaberg (Saxony). She married the owner of several mines. After her husband's death around 1550, she continued to supervise the mines and smelters, developing a profitable business. Barbara Uttmann also introduced the art of making bobbin-lace to Saxony, creating an important economic enterprise for the women of that region, who since the end of the 14th century had been gradually forced out of the craftsmen's guilds (Kuhn, 1992).

Towards the end of the 18th century, science began to be professionalized especially in Germany and France, whereas concomitantly as a result of the onset of industrialisation family life was "privatized". These processes promoted a rigid division of labour in the wealthier families, the man going forth into the "hostile world", whereas the housewife stayed at home, attending to her duties concerning household and children. This divided the sphere of living for men and women more completely than had been the case in previous centuries. Only at the bottom of the social scale were the distinctions less marked, with women and children working like beasts of burden in coal mines and later in the factories of the early stages of the Industrial Revolution. They also continued as agricultural workers (Grubitzsch, 1992).
Australia's First Lady: Dorothy Hill (1907-1997) was one of the most influential Palaeozoic coral palaeontologist in the second half of the 20th century. She spent most of her academic life at the University of Queensland (Australia). She co-authored the Anthozoa section of the Treatise on Invertebrate Palaeontology and was sole author of the revised and enlarged section on Archaeocyathida. Her enlargement and revision of the section on Rugosa and Tabulata as a supplement to the Treatise (1981) is hugely influential to the present day.

Hill was the first female President of the Australian Academy of Sciences (1956) and the first woman holding a Chair at an Australian university (1959) (Scrutton, 1999).

Careers and Family for Both: Helen Tappan Loeblich and her future husband Alfred Loeblich met as students at The University of Oklahoma. The two students did most of their field-work together, with Helen's father acting as chauffeur and chaperone (it was the 1930s).

This was the start of a fruitful collaboration which, contrary to that of many other couples, survived marriage and children. Helen got her foot into teaching and also into the USGS when her husband, along with many other young male geologists, was called into army service during World War II. In the 1950s Helen and Alfred worked on the foraminifera volumes of the Treatise on Invertebrate Palaeontology, their four children attended by a grandmother always with them.

From 1958 until 1985 Helen Tappan Loeblich taught at UCLA and her husband worked in the oil industry, organising many joint projects with his wife (Loeblich, 1993).

Using Innovative Tools: Around 1969, while still a graduate student, U.S. American geologist Tanya Atwater, in using magnetic anomaly patterns from the Pacific Ocean floor, advanced a totally new approach to unravel the Cenozoic processes of western North America. Drawing on the then new concept of plate tectonics, she demonstrated its usefulness and capability. This first step from theoretical considerations to practical use, which she successfully defended against a sceptical audience, was crucial for the acceptance of plate tectonics (LeGrand, 2000).

Still Living in the Ice Age: Voices at the End of the 20th Century: "Nobody will employ a female geologist" (Tübingen, 1989). - Argument of an elderly anthropologist against the establishment of an equal opportunity act for the faculty of geosciences at a German university: "We are abandoning our biological foundations!" (Germany, 1993). - "She won't need the job. She is married, so her husband can earn the family-money" (Karlsruhe, 1995). - "What is your husband's opinion, concerning your application for this job?" (Karlsruhe, 1995). - "Women who seek to combine career and family undermine the occidental social order" (Munich, 1998)

Sources for portraits: Rietschel (1985), Torrens (1985), Lang (1950), Graham (1824), Gordon (1894), Faul \& Faul (1983), Weitzenhoffer (1987), Rickards (1999), Creese (1996), Rossiter (1982), Gates (1998), Sinclair (1966), Hofer (1969), Scrutton (1999), Loeblich (1993), Peg O'Malley (http://www-rohan.sdsu.edu/ 3gleep6/footnote5.html)

On the other end of the social scale, women of the European aristocracy had more than ample time and some of them transformed boredom into curiosity about natural history rather than stitching tapestry. For such women, collecting minerals, fossils and other curiosities became a pleasurable leisure occupation. For example, Markgräfin Caroline Luise von Baden (1723-1783) built up an extensive natural-history collection, scientifically organized. To develop the collection which focused on minerals and fossils but included also some plants and stuffed animals, she corresponded with other sovereigns, scientists, collectors, and dealers. Her collection became the nucleus of the State Museum for Natural History in Karlsruhe (Trunko, 1985).

Around the beginning of the 19th century, geology emerged as a science and the number of male geologists began to increase more or less steadily. However, the much smaller number of female geologists was strongly modulated by social, political and historical factors. These factors become most obvious, when we compare two culturally related but nevertheless extremely different "species" of the "genus" Woman-Geologist: W-G. germanica from Germany and WG. britannica native to the United Kingdom (see Figure 2). 
Whereas the number of male geologists has increased more or less steadily since geology emerged as a science around the beginning of the 19th century, the much smaller number of female geologists was strongly modulated by social, political and historical factors. These factors become most obvious, when we compare two extreme "species" of the "genus" Woman-Geologist: $W$-G. germanica from Germany and $W$-G. britannica native to the United Kingdom.

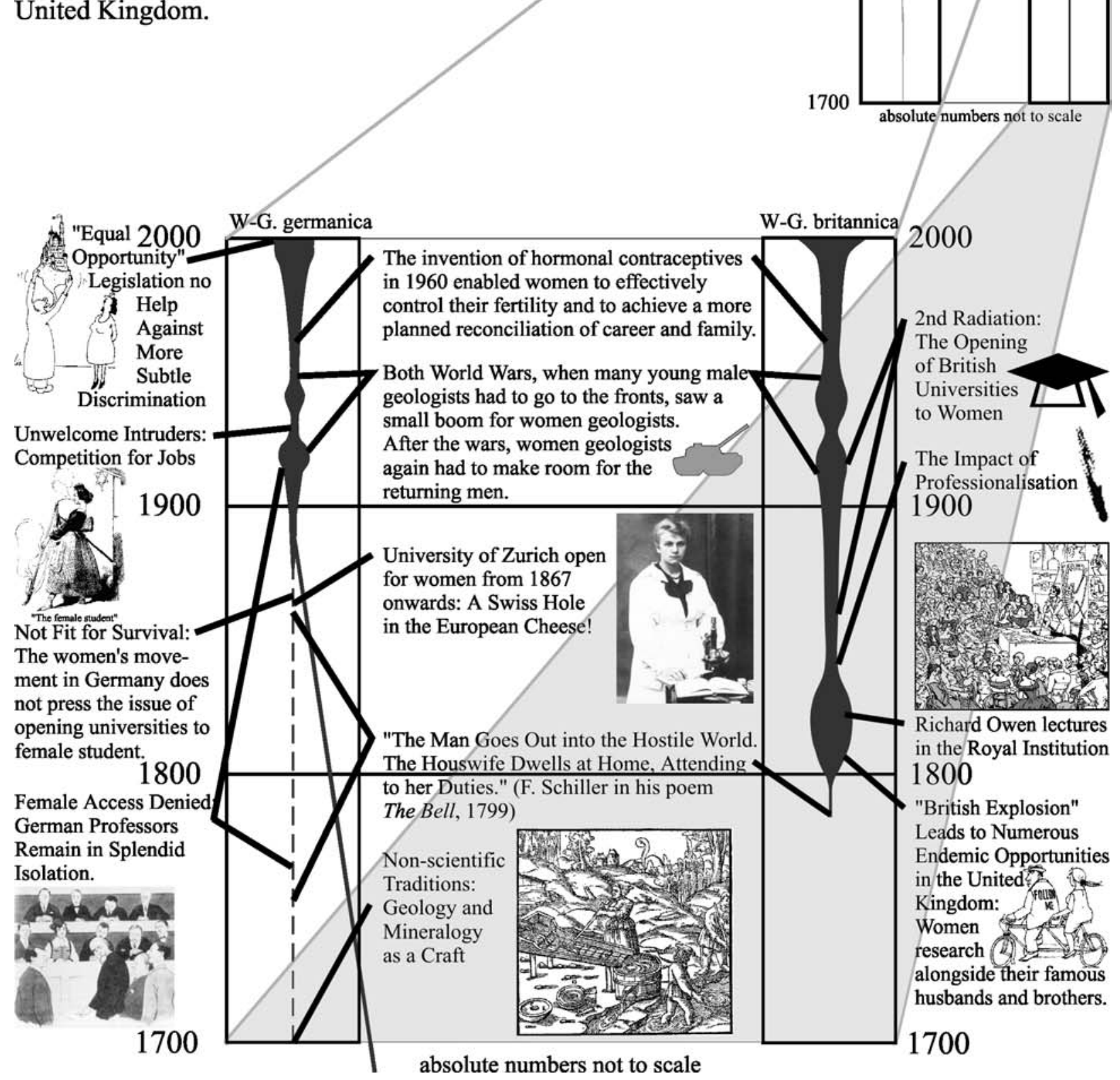

Figure 2 Graphical illustration of the number of female geologists in Germany and the United Kingdom throughout the last three centuries. Sources for figures: cartoons by Stauber \& Liebermann, Owen's lecture-cartoon from contemporary "Punch", Göpel (1986), Häntzschel \& Bußmann (1997), Kuhn (1992), Agricola (1556). 


\section{From the "British explosion" to the impact of professionalization}

In the early 19th century in the United Kingdom much of geology was not yet professionally organized, but outside industrial geoscience remained a private interest for people with sufficient money, time and leisure to study, travel and publish. In these informal, nonprofessional surroundings, British women were not yet rivals in the competition for jobs, and under such circumstances were welcomed — within the restrictions of the social order — as fellow-enthusiasts, often working for their husbands or brothers, but also for non-relatives. Many of them formed networks of assistants, collectors, illustrators, editors, field geologists, taxonomists and travel-companions to the leading figures in the geological sciences, thereby adding to and shaping their work (Kölbl-Ebert, in press).

Well before her marriage, Mary Morland (1797-1857) who eventually married the palaeontologist and Oxford don William Buckland had made a name as a scientific draughtswoman, contributing to the work of Conybeare and Cuvier. After her marriage, she continued to do geological work, accompanying her husband on field trips, making observations, illustrations and models, and assisting in the collection of specimens and the preparation of papers. All this though she gave birth to nine children (Kölbl-Ebert, 1997a).

Mary Morland was no exception in her time: Charlotte Murchison (1788-1869) conducted geological field work with her husband Roderick Murchison in the United Kingdom and on the Continent. The Murchisons achieved an effective division of labour, which made her husband one of the most productive geologists of his time. Charlotte's task was fossil-hunting and sketching of outcrops and landscapes. She also helped to prepare her husband's publications. Many of her illustrations appeared in her husband's papers and books (Kölbl-Ebert, 1997b).

In the common way of presenting history of science as succession of ideas arrived at by individuals, such collaborations and interdependencies are largely ignored and thus the work of two or more is attributed to one.

Although palaeontology and stratigraphy were the primary spheres of the early British women geologists, they were by no means restricted to these topics. In November 1822, part of the Chilean Coast was devastated by an intense earthquake. The report of this geological phenomenon by Maria Graham (1785-1842) was one of the earliest geologically meaningful descriptions of such an event. It gave rise to a vituperative debate at the Geological Society of London about earthquakes and their role in mountain building. Graham's account was entirely reasonable from a present-day view, but she became trapped between the millstones of two conflicting theories, neither of which was correct (Kölbl-Ebert, 1999).

Maybe the best-known woman palaeontologist of the early $19^{\text {th }}$ century is Mary Anning (1799-1847), who practised geology for a living, and thus might be regarded as the first female professional in this business. Mary Anning, fossil dealer of Lyme Regis (Dorset, U.K.), provided palaeontology with numerous well-prepared and scientifically valuable specimens from the Blue Lias around her native town, among which were the first ichthyosaurs to be described, the first complete plesiosaurs ever found and the first British pterosaur, not to mention fish and countless invertebrate fossils. Mary Anning was no mere treasure hunter, but an adept business woman, she took her time to observe closely and worked as informant and field geologist to many palaeontologists such as William Buckland, William Conybeare and Henry De la Beche. Her observations confirmed the origin of certain coprolites and solved questions concerning the mode of life of fossil Jurassic crinoids (Taylor \& Torrens, 1987; Torrens, 1995, and references therein).

A very small number of the early British female geologists researched as private scholars for their own "fame". They were usually from the aristocracy and financially independent. The most notable of these lady geologists was Etheldred Benett (1775-1845), who spent much time on fossil collecting and stratigraphical work, which led to one of the earliest detailed quarry sections published in England. Many of her specimens are depicted in Sowerby's Mineral Conchology of Great Britain (1812 ff.). She contributed stratigraphical information to Greenough's Geological Map of England and Wales and published a stratigraphically arranged catalogue of the specimens in her collection, including many new species (Benett, 1831). Her name appears frequently in the list of donations to the Geological Society. She also presented fossils to individual geologists and to museums, among them one in St Petersburg. The Tsar (assuming Etheldred must be male) had the University of St Petersburg award her an honorary diploma (Creese \& Creese 1994, Torrens 1985, Spamer et al. 1989, Torrens et al. 2000).

However, the women of the early 19th century depended on help from male relatives for their geological work, since they had difficulties in visiting public lectures or libraries without chaperones (Somerville, 1873). Nevertheless, some sort of geological education was available to women in addition to books and private tuition. In 1831, Charles Lyell became lecturer at King's College, London. After an initial dispute at the Geological Society of London it was decided by the University Council that ladies were to be admitted to the course. The following year, however, the College governors changed their minds, and (in Lyell's words) "determined ... that ladies should not enter my lecture-room, because it diverted the attention of the young students, of whom I had two in number from the college last year, and two this. My class being [sic] thus cut down to fifteen." But fortunately this was not the end: "The Royal Institution, hearing that the ... College ... [would] not admit ladies, ... sent me an invitation of a pressing kind to give them some six or eight lectures after Easter. ... I consented to seven lectures, which have been attended by 250 persons (scarce ever less), about a hundred of them men. ... I regret that the bishops cut short my career at King's College, ... but there seem[ed] no way of having a large audience but by one of two methods - an academical class, or one open to women as well as men" (K.M. Lyell, 1881, vol. I, pp. 395-397).

The public lectures at the Royal Institution were so popular among women that they even featured in W.M. Thackeray's novel Vanity Fair (1847), where the author remarked of his heroines: "Some of the Ladies were very blue [i.e. they counted as 'blue-stockings'] and well-informed, reading Mrs. Somerville and frequenting the Royal Institution." This Mrs. Somerville (1780-1872) was an accomplished mathematician and astronomer, who wrote books on various sciences. Among these On the Connexion of Physical Sciences and Physical Geography included geological knowledge. The books were best-sellers, and they were constantly revised in numerous editions which kept them at the very frontier of scientific research. In 1866, the progressive philosopher John Stuart Mill initiated a petition for women's right to vote. Mary Somerville was the first of 1500 subscribers (Somerville, 1873). But the right to vote for British women was not granted until 1918 (see Table 1).

However, the relatively favourable conditions for female coworkers in the United Kingdom lasted only until geology gained in intellectual and social status and became recognised in universities during the second half of the 19th century. Women now were largely excluded notably from the Geological Survey and from the brotherhood of mining engineers, since the opening of British universities to women was still in its infancy. As professionalisation developed, female co-workers and lady geologists became a declining species, along with the gentlemen geologists.

\section{The stagnant pool of Germany}

Whereas throughout the first half of the 19th century, British geology had experienced a modest radiation among women geologists leading to numerous endemic opportunities in the United Kingdom, matters were very different in the German states. Female access was denied, and German professors remained in splendid male isolation.

In German States and neighbouring countries geology had developed from a technical, mineralogical tradition, which stemmed 
Table 1 Votes for women

When did women receive the right to vote?

Here are a few examples:

\begin{tabular}{ll}
\hline 1869 & Wyoming (USA) \\
1902 & Australia \\
1906 & Finland \\
1913 & Norway \\
1915 & Denmark, Iceland \\
1917 & Soviet Union, Canada, Netherlands \\
1918 & United Kingdom, Germany, Ireland \\
1919 & Austria, Poland, Sweden, Czechoslovakia \\
1920 & USA \\
1924 & Mongolia \\
1929 & Ecuador \\
1931 & Ceylon, Spain \\
1932 & Brazil, Thailand, Uruguay \\
1934 & Cuba, Turkey \\
1935 & India \\
1937 & Philippines \\
1944 & France \\
1945 & Italy, Liberia \\
1946 & Japan, Albania, Yugoslavia, Panama, South Africa \\
1947 & China, Argentina, Venezuela \\
1948 & Belgium, Israel, Korea \\
1949 & Chile, Costa Rica, Hungary \\
1952 & Greece \\
1971 & Switzerland \\
1990 & Kanton Appenzell (Switzerland) \\
& \\
\hline
\end{tabular}

Sources: Bundesministerium für Frauen und Jugend (1993); U. Marvin, pers. comm.

from the early establishment of schools of mines, leading to early professionalisation of the geosciences. The male domination through both mining and in formal training precluded the emergence of women geologists until the early 20th century. With few exceptions, women in Germany were debarred from posts in the universities until the 1920s. One of the reasons which hampered the admission of women to universities and to the professions was the high social status and salaries accorded to university qualifications and posts in Germany. In Prussia, the social ranking of a university professor was comparable to that of a state minister, the income of a professor at the end of the 19th century being about eight times that of a teacher at an elementary school (Costas, 1997). Also, the British tradition of more or less independent colleges linked so as to form a university was easier to accommodate female students and dons, since, where women's colleges were established at London, Oxford, and Cambridge, it allowed an initial sexual apartheid, whereas the structure of German universities provoked instant confrontation.

However, women themselves often proved not fit for political survival through lack of ambition and self-confidence, e.g., in the 1860s, the Allgemeine Deutsche Frauenverein (General German Women's Federation) proclaimed the right of only unmarried women to jobs and education. Since the general idea was that the aims for women's education should be restricted to jobs such as teaching, which were easily reconciled with traditional women's roles, such petitions for reform in female education did not demand admission to the Abitur or university admissions examination. However, as more and more German women went to study in Switzerland, they were at last enabled to prepare in Germany for this crucial examination (Costas, 1997).

In 1867, the University of Zurich (Switzerland) had been one of the first universities on the Continent to open its doors to women undergraduates (see Table 2). Many women came from Germany, Russia, and Eastern Europe to study there. Moreover, many liberalminded professors came to Switzerland as fugitives after the $1848 \mathrm{rev-}$ olutions. But in 1873 a decree of the Tsar prohibited Russian women from studying in Switzerland. In 1900, Baden was the first German state to admit women to universities (Costas 1997, Rupp 1978).

\section{University education triggers a new radiation}

British legislation gave women the right to university education in 1876. Though not formally admitted to degrees of the Universities of Oxford and Cambridge, women did apply and were able to sit the entrance examinations. Colleges for women were established at these two Universities from 1865 and 1869 onwards, and female students could sit the university examinations, but actual degrees were not formally awarded before the next century: in 1920 at Oxford and only in 1948 at Cambridge. The 'Red Brick' or municipal universities in Britain, founded as colleges in industrial cities, mainly in the 1880 s, admitted women as undergraduates as a matter of course. By the last decades of the 19th century, women in Britain could get a science education that included geology. Bedford College, London, specially catered for female students (Alic, 1986; B. Hamilton, pers. comm.).

A notable pioneer woman geologist with university training was Catherine Raisin (1855-1945). She read geology, botany and zoology at University College London. After graduating in 1884, she continued to work at UCL as voluntary assistant to the well-known petrologist T.G. Bonney and they co-authored some important papers on Welsh geology. In 1890, she became head of the Geology Department at Bedford College for Women and later was also in charge of its Botany Department. In 1893, she was the first woman to receive the Lyell Fund of the Geological Society, but was not allowed to accept the award in person since women were not admitted to the Society's meetings before 1919. Raisin researched mostly in petrology and mineralogy, and was an excellent microscopist. Working in South Devon in the late 1880s, she was one of the first geologists to map different metamorphic facies (Creese \& Creese, 1994).

Among those early, university-educated women geologists were also e.g. Gertrude Elles and Ethel Wood. Trained at Cambridge, Gertrude Elles (1872-1960) worked heroically on the preparation of British Graptolites, a monograph that was produced over two decades (1901-1914) under the editorship of Charles Lapworth (Birmingham). Elles wrote the descriptive texts and her friend Ethel Wood (1871-1946), also a student at Cambridge, prepared the illustrations. They gave detailed descriptions of virtually every species of this previously confused group of fossils, and the monograph remained the standard work on graptolites for decades. Elles also worked on Lower Palaeozoic stratigraphy and on metamorphic rocks in Scotland. She taught geology at Cambridge for many years, supervising male students, but for the first 30 years of her teaching career remained without official university position. She belatedly received a Cambridge ScD in 1949 (Rickards, 1999).

Matters for these women were certainly not easy, since they were regarded often as unwelcome intruders in the competition for jobs. "As a general rule, the scientific woman must be strong enough to stand alone, able to bear the often unjust sarcasm and dislike of men who are jealous of seeing what they consider their own field invaded" (Henrietta Bolton, 1898, in Popular Scientific Monthly).

There was a general tendency for those women who did enter geology, to specialise in palaeontology rather than petrology. A reason might have been that palaeontology until well into the 20th century did not need the laboratories or instruments that were only available in universities and other research institutions. Palaeontology could be done to a large extent in isolation. Sometimes, women were encouraged to specialise in micropalaeontology, because this was considered "no occupation for a man" (pers. comm. Prof. Trümpy, Zurich).

Another typical occupation for women was to be employed as "computers", i.e. people who—as assistant to a scientist—organised 
and computed data. One of them was, e.g., U. S. American geologist and oceanographer Marie Tharp, who as assistant to Bruce Heezen compiled his echolocation data into topographic maps of the ocean floors visualizing the geological structure of the oceanic crust with Mid-Ocean Ridges, Seamounts and Trenches (Barton, unpubl. manuscript, 2000). However, with the development of modern computer technology, the human computers lost their important function.

In the late 1940s and 1950s, a disproportionally high number of women geologists joined the Water Department of the British Geological Survey, which was seen as the only opportunity for women to conduct field work (Plant et al., 1994).

In Germany, the admission of women to universities and academic professions started some 30 to 50 years later than in the USA, the United Kingdom, France, and other countries (see Table 2), and to this day the female university teacher remains the exception in Germany (Costas, 1997).

At many German universities the first women to receive $\mathrm{PhDs}$ were foreign students who came to study in Germany having already completed their studies in their home countries. They were important in smoothing the path for German women, by demonstrating that women are capable of scientific work of the highest quality. On July 25th, 1900, British palaeontologist and Alpine geologist Maria Mathilda Ogilvie-Gordon (1864-1939) was among the first two females to received a doctorate from the University of Munich, where she studied for four years, by special permission, under Karl von Zittel (Creese, 1996; Meister, 1997).

Maria Ogilvie-Gordon also received in London the first DSc (1893) in geology awarded to a woman in the United Kingdom. Her life-long distinguished and much awarded, but always unpaid career in geology was concerned with the tectonically complex structure of South Tyrol, involving arduous fieldwork in difficult terrain, and with fossil and recent corals. Her publications were substantial, many appearing in Austrian journals. In 1895 she married and subsequently had three children. She also pursued an important second career as a civic and social leader concerned with the advancement of women and the welfare of children and young people (Creese, 1996). In history of geology, she is well-known for her English translation of Zittel's History of Geology and Palaeontology.

\section{The early 20th Century: transgression and regression}

Both World Wars, when many young male geologists had to go to the fronts, saw a small boom for women geologists in Germany, Britain, and elsewhere. But with the end of the wars, professional women geologists, and also female students, again had to depart in order to make room for the returning men. Women not willing to do so were abused as war profiteers. For example, Tekla Hoyermann was assistant professor in geology from 1914 to 1918, but then lost this position. Thus she was the only female geologist employed on the academic staff at the University of Tübingen until the 1990s (Engelhardt \& Hölder, 1977). Likewise, the British Geological Survey hired women during World War II to help the survey's war effort. A female member of the staff, Miss Eileen M. Gruppy, was promoted in 1943 and reverted again after the war, because it was deemed that she had fulfilled her wartime role (Plant et al., 1994).

After World War I, only around $10 \%$ of the science students in Germany were female, partly because the difficult economic situation led families to send their sons rather then their daughters to universities. By the early 1930s the percentage of women among students of natural sciences had risen to about $20 \%$. The University of Munich was especially favoured by women students. Here nearly $29 \%$ of the science students were female, most of them endeavouring to become chemists. With the beginning of a worldwide economic crisis in 1929 female students encountered increasing opposition. Because of a high rate of unemployment among academics the pressure was especially high on so-called Doppelverdiener ("dou-

\section{Table 2 Higher education for women}

When were Women admitted to Study at Universities?

Here are some examples:

1840

first women admitted as guests at the Univer sity of Zurich

1850 first women's college in Philadelphia (USA)

1863 Paris (France): all subjects with the exception of theology

1865 first women's college at the University of Oxford (women not admitted to university degrees)

1867 University of Zurich

1869 first women's college at the University of Cambridge (women not admitted to university degrees)

$1870 \quad$ Sweden

$1871 \quad$ Finland upon request

1872 Russia: women were allowed to study medicine

1875 Denmark

$1876 \quad$ United Kingdom, Italy

1878 Portugal

$1879 \quad$ Netherlands

$1880 \quad$ Norway

$1883 \quad$ Belgium

$1888 \quad$ Spain

1892 first female student with special permission at the University of Tübingen (Germany)

1893 Turkey acknowledges female physicians from abroad

1895 Hungary

1896 Greece

1897 Poland, Austria partly, a few women as guests at the University of Tübingen (Germany)

1900 Baden (Germany)

USA: all universities open to women

$1901 \quad$ Finland generally

1903 Bavaria (Germany)

1904 Württemberg (Germany)

1908 Prussia (Germany)

1920 women admitted to degrees at Oxford

1948 women admitted to degrees at Cambridge

Sources: Alic (1986), Rupp (1978), Junginger

(1991)

ble-earners"), i.e. couples where both husband and wife occupied academic jobs. From May 30th, 1932 onwards, a new law allowed the dismissal of tenured female state employees, if they were supported by a husband (Nagler-Springmann, 1995).

However, discrimination against married female scientists was no speciality of Germany. In the 1920s, when the British Geological Survey started to recruit women geologists, it was stated in the advertisements that female candidates "must be unmarried or widowed and will be required to resign their appointments on marriage" (Plant et al., 1994).

Women were not established as a natural part of the German scientific system when the Nazis came to power in 1933. During the following years, about half of the some 70 women with Habilitation (i.e. qualified for a professorship) were expelled on racist or political grounds, forced into exile, deported, or murdered; along with many other female scientists or students (Costas 1997, p. 34).

A successful fugitive was Tilly Edinger (1897-1967), but who knows how many failed? Edinger started her career as a curator for vertebrate palaeontology at the Senckenberg Museum in Frankfurt am Main. She worked on fossil brains, creating a new branch of science: Palaeo-neurology. But because of her Jewish descent she had 
to resign her position in 1938, and two years later fled from Germany under great difficulties. Via England she emigrated to the USA, where she eventually found employment at the Museum for Comparative Zoology at Harvard (Hofer, 1969).

The campaign against Doppelverdiener continued, and Naziideology encouraged unmarried women to pursue careers that were deemed seemly for the female way of life. These did not include science and technology. However, this was only achieved in practise where the German state from the central government down to the communities functioned as the employer, e.g. in universities or in geological surveys. Married women lost their jobs, and the remaining spinsters had to settle for less money than their male colleagues. Promotion for women was denied, and women in higher positions were downgraded. In 1933, a quota of $10 \%$ for new female students was introduced. Although this law was rescinded two years later, until 1939 the number of female students dropped by about two thirds. Additionally the ideological role model had a considerable influence on the choice of subjects. In 1938, only $7.6 \%$ of sciences students were female. During World War II, however, the percentage of female students increased dramatically. Young men had to become soldiers instead of students, and women were again sought as scientists and technicians to replace the men, who went to the fronts. By 1943/44 the percentage of women among science students rose to more than $60 \%$. Even so, this did not lead to a lasting change in the ideological role model for women. The war effort was simply regarded as a temporary state of affair. When the men returned to the universities, the percentage of female science students in Munich dropped to $28 \%$ in 1946. This downward trend continued until 1957 , when the number reached 15\% (Nagler-Springmann, 1995). Female scientists continually had to fight against male prejudice. In the 1950s more than one third of West German professors thought that women were incapable of following a scientific career (Costas, 1997, p. 34). It took until the late 1970s for the percentage of female science students in West Germany to rise to the level it had had in the early 1930s (Nagler-Springmann, 1995).

From 1960 onwards, the invention of hormonal contraceptives enabled women to effectively control their fertility and achieve a more planned reconciliation of career and family; an achievement, which can hardly be overestimated. An increased awareness of discrimination against women in Western society, made from the late 1970s onwards, first steps possible towards an equal opportunity legislation, which eventually - in the 1990s - showed effect in Britain. In Germany of the 1990s, however, there were continuing signs of stagnation (compare Figure 3), which made Londa Schiebinger suggest that the "Federal Republic of Germany has the distinction of being one of the worst possible places for academic women" (Schiebinger, 1999).

In the former German Democratic Republic (East Germany), the employment of women was generally accepted and officially welcomed. Thus in the late 1980 s, about $90 \%$ of women of employable age were in the workforce, compared to some 55\% in West Germany. The planned economy of East Germany directed students' university subjects, as a result of which there were $46 \%$ female science students in 1989 compared to only $35 \%$ in West Germany. However, an inquiry conducted in 1985, showed that $35-38 \%$ of female students in engineering, sciences and economics initially wanted to study some other subject, and would have done so had they been allowed to. As in the West, women were only a small minority in higher positions. For example, in 1983 we find that $35 \%$ of the students at the Technical University of Dresden, $27.5 \%$ of the untenured Assistenten (comparable to assistant professors), between 26.5 and $13.7 \%$ of the tenured staff in the middle ranks, $4.8 \%$ of the professors, and only $1.9 \%$ of the professors holding chairs were female. After German reunification in 1990, the staff of eastern universities was reduced, with the introduction of new structures. Women were particularly affected by the staff reductions. Thus from $1989 / 90$ to 1996 the proportion of women in the middle ranks at the eastern universities declined from $38,5 \%$ to $32,7 \%$ (averaged over all subjects-no specific data on geology are available) (Wissenschaftsrat, 1998, A.IV.3.).

From 1993 onwards, the data compiled in Table 3 include the territory of the former German Democratic Republic. However, there is no break in the trends shown in Figure 3. Either the statistical situation of female geologists in the East German universities has been similar to that in the West, an assumption which contradicts the personal impression of eastern colleagues (per. comm., Peter Krüger

Table 3 Proportion of women earth scientists (geologists, mineralogists, palaeontologists and geophysicists) at universities of the Federal Republic of Germany (1980-1998). From 1993 onwards, the data include also the territory of the former German Democratic Republic. Data courtesy Statistisches Bundesamt (Federal Republic of Germany).

\begin{tabular}{|c|c|c|c|c|c|c|c|c|c|c|c|c|c|c|c|c|c|c|c|c|}
\hline Status & year & 1980 & 1981 & 1982 & 1983 & 1984 & 1985 & 1986 & 1987 & 1988 & 1989 & 1990 & 1991 & 1992 & 1993 & 1994 & 1995 & 1996 & 1997 & 1998 \\
\hline \multirow[t]{3}{*}{ Students } & total & 8558 & 9440 & 10394 & 10960 & 11320 & 11336 & 11252 & 11132 & 11178 & 11023 & 11411 & 11356 & 11804 & 11996 & 11795 & 11495 & 11047 & 10788 & 10230 \\
\hline & women & 1890 & 2182 & 2461 & 2575 & 2640 & 2658 & 2649 & 2699 & 2774 & 2842 & 3016 & 3066 & 3320 & 3455 & 3460 & 3493 & 3544 & 3593 & 3577 \\
\hline & percentage & 22.1 & 23.1 & 23.7 & 23.5 & 23.3 & 23.4 & 23.5 & 24.2 & 24.8 & 25.8 & 26.4 & 27.0 & 28.1 & 28.8 & 29.3 & 30.4 & 32.1 & 33.3 & 35.0 \\
\hline \multirow[t]{3}{*}{ Diplomas } & total & n.d. & n.d. & n.d. & 611 & 603 & 659 & 695 & 723 & 814 & 919 & 949 & 1030 & 869 & 872 & 814 & 794 & 777 & 838 & 821 \\
\hline & women & n.d. & n.d. & n.d. & 153 & 128 & 134 & 146 & 153 & 181 & 218 & 214 & 269 & 210 & 238 & 224 & 197 & 234 & 232 & 244 \\
\hline & percentage & n.d. & n.d. & n.d. & 25.0 & 21.2 & 20.3 & 21.0 & 21.2 & 22.2 & 23.7 & 22.6 & 26.1 & 24.2 & 27.3 & 27.5 & 24.8 & 30.1 & 27.7 & 29.7 \\
\hline \multirow[t]{3}{*}{ Doctorates } & total & n.d. & n.d. & n.d. & 207 & 217 & 193 & 210 & 242 & 239 & 272 & 236 & 278 & 266 & 268 & 293 & 283 & 289 & 286 & 268 \\
\hline & women & n.d. & n.d. & n.d. & 28 & 32 & 35 & 31 & 42 & 40 & 47 & 46 & 50 & 44 & 43 & 65 & 55 & 61 & 69 & 60 \\
\hline & percentage & n.d. & n.d. & n.d. & 13.5 & 14.7 & 18.1 & 14.8 & 17.4 & 16.7 & 17.3 & 19.5 & 18.0 & 16.5 & 16.0 & 22.2 & 19.4 & 21.1 & 24.1 & 22.4 \\
\hline \multirow[t]{3}{*}{ Staff } & total & n.d. & n.d. & 1527 & n.d. & n.d. & 1743 & 1863 & 1880 & 2087 & n.d. & 2122 & 2058 & 2217 & 2290 & 2374 & 2416 & 2428 & 2363 & 2377 \\
\hline & women & n.d. & n.d. & 134 & n.d. & n.d. & 169 & 215 & 238 & 271 & n.d. & 281 & 297 & 322 & 371 & 385 & 391 & 390 & 371 & 400 \\
\hline & percentage & n.d. & n.d. & 8.8 & n.d. & n.d. & 9.7 & 11.5 & 12.7 & 13.0 & n.d. & 13.2 & 14.4 & 14.5 & 16.2 & 16.2 & 16.2 & 16.1 & 15.7 & 16.8 \\
\hline \multirow[t]{3}{*}{ Habilitation } & total & 16 & 17 & 13 & 16 & 20 & 21 & 16 & 25 & 29 & 23 & 29 & 21 & 34 & 32 & 31 & 33 & 38 & 44 & 58 \\
\hline & women & 0 & 1 & 1 & 0 & 0 & 0 & 0 & 3 & 1 & 0 & 0 & 0 & 2 & 4 & 2 & 6 & 4 & 6 & 8 \\
\hline & percentage & 0.0 & 5.9 & 7.7 & 0.0 & 0.0 & 0.0 & 0.0 & 12.0 & 3.4 & 0.0 & 0.0 & 0.0 & 5.9 & 12.5 & 6.5 & 18.2 & 10.5 & 13.6 & 13.8 \\
\hline \multirow[t]{3}{*}{ Professors } & total & n.d. & n.d. & 422 & n.d. & n.d. & 464 & 454 & 443 & 442 & n.d. & 468 & 444 & 463 & 478 & 467 & 463 & 467 & 453 & 429 \\
\hline & women & n.d. & n.d. & 7 & n.d. & n.d. & 5 & 5 & 5 & 4 & n.d. & 7 & 7 & 4 & 5 & 4 & 7 & 8 & 10 & 12 \\
\hline & percentage & n.d. & n.d. & 1.7 & n.d. & n.d. & 1.1 & 1.1 & 1.1 & 0.9 & n.d. & 1.5 & 1.6 & 0.9 & 1.0 & 0.9 & 1.5 & 1.7 & 2.2 & 2.8 \\
\hline \multirow[t]{3}{*}{ Chairs } & total & n.d. & n.d. & 140 & n.d. & n.d. & 157 & 153 & 153 & 157 & n.d. & 163 & 152 & 191 & 173 & 170 & 178 & 187 & 181 & 179 \\
\hline & women & n.d. & n.d. & 1 & n.d. & n.d. & 1 & 1 & 2 & 2 & n.d. & 2 & 3 & 2 & 2 & 1 & 2 & 2 & 2 & 4 \\
\hline & percentage & n.d. & n.d. & 0.7 & n.d. & n.d. & 0.6 & 0.7 & 1.3 & 1.3 & n.d. & 1.2 & 2.0 & 1.0 & 1.2 & 0.6 & 1.1 & 1.1 & 1.1 & 2.2 \\
\hline
\end{tabular}




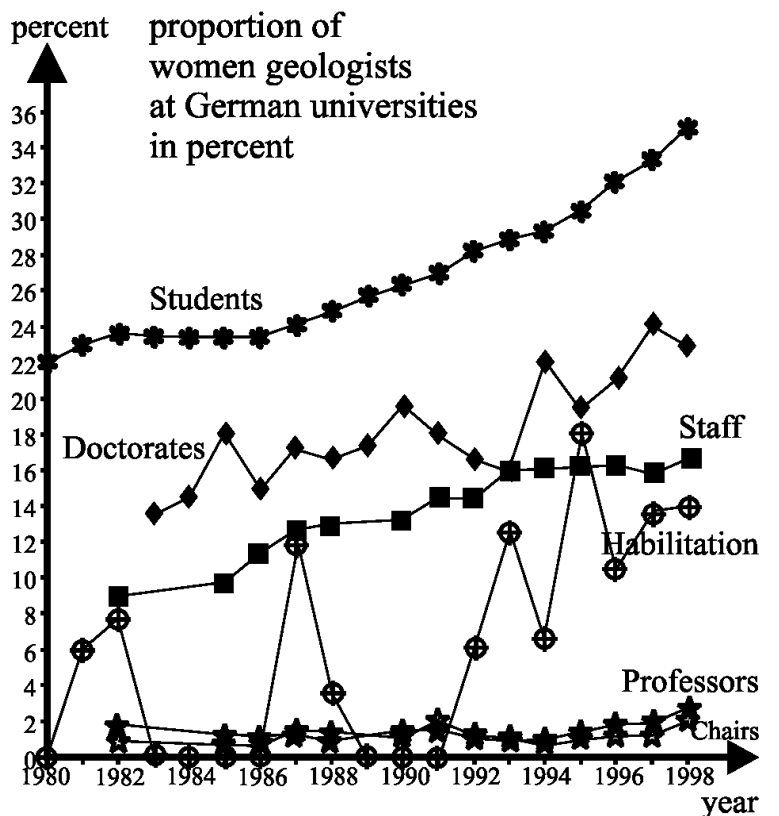

Figure 3 Proportion of women earth scientists (geologists, mineralogists, palaeontologists and geophysicists) at German universities (1980-1998). From 1993 onwards the data include also the territory of the former German Democratic Republic. Data courtesy Statistisches Bundesamt (Federal Republic of Germany).

and Annette Vogt, Berlin), or the brief period of three years was sufficient to "westernize" the proportions of men and women geologists.

\section{The last two decades: women geologists still living in the ice-age}

German universities are organised strictly hierarchically, and as in most hierarchies the higher the position is, the less women we find. This becomes immediately clear from the statistical data for geology of the last two decades (Table 3, Figure 3; data courtesy Statistisches Bundesamt, Germany). The proportion of female geology students has risen steadily since around 1987 and reached 35\% in 1998. Also the female doctorate candidates show an increasing trend, albeit not as steady as that for undergraduate students. The proportion of female scientific staff members of the geology departments of German universities also nearly doubled from $8.8 \%$ in 1982 to $16.2 \%$ in 1993 , only to remain stagnant on that level, although an ever increasing number of qualified women geologists (with doctorate degrees or Habilitation) became available. Since most of the positions which sum up to those figures are temporary, there is no way of arguing that no geology positions were available on the job market. At the upper end of the hierarchy, the proportion of female geology professors remained at an extremely low level during the last two decades of the 20th century, and it remains to be seen, whether the slight increase within the last two years from 1.7 to $2.8 \%$ is going to establish a positive trend.

Considering these figures, female geologists in Germany are clearly less fortunate than their colleagues from other subjects, since in 1998 on the average $9.5 \%$ of Germany's professors were female. This figure has risen from $7.5 \%$ in 1995 for all German professorships. Even if we regard science only, the situation in geology is decidedly below average: In $19953.4 \%$ of the science professors were female; geology and physics/astronomy marking the bottom

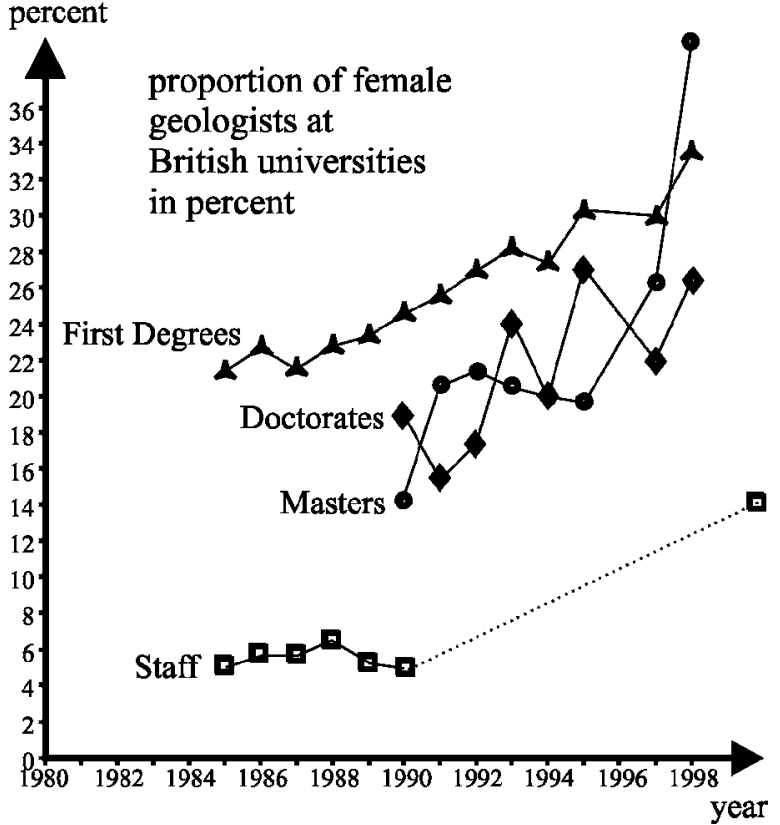

Figure 4 Proportion of women earth scientists at British universities (1980-1998). Data from Bottomley (1992-1996), Ward (1992, 1997-2000). Extrapolation of the proportion of female staff into the present due to a brief internet survey of British university homepages, January 2001.

end of the statistics with 1.5 and $1.4 \%$ female professors respectively. This was worse even than e.g. catholic theology or mathematics, both of which in 1995 had a proportion of 3.4\% female professors (Source: Statistisches Bundesamt, FRG).

Notwithstanding the many achievements in recent years, the present culture of the geosciences at least in Germany is not obviously welcoming to women. Discouraging or discriminating remarks (see Figure 1), which many German women geologists can recount from personal experience represent only the tip of an iceberg, most of which is submerged in the subconscious of the "malefactors". Therefore it is hardly astonishing that many would-be employers or colleagues of women geologists are unaware of a discriminating attitude. They often act out of good-willing, paternalistic concern: "No, we cannot give the job to this woman. She has children and how should she manage." - "She is too young and tender, the strain of the field work would be too much for her." — "She wouldn't like the rough treatment by the workers on the building-site." - "She'll be unhappy because she'll not be able to carry her point." - "She is married therefore she cannot move house, and if she has to drive to work such a long way every day, she won't stand it for long."- And many a professor patronizingly explains to would-be female $\mathrm{PhD}$ candidates that careers and children do not go together (all examples courtesy members of the Commission for Equal Opportunity at a German university, collected during the 1990s; see also Wissenschaftsrat 1998, A.IV.1.).

Also, Equal Opportunity Legislation achieves little, when people have learned to discriminate in more subtle ways: Qualifications are minimised or even ignored. The female applicant is either too young or too old, or her vita does not exactly 'fit the team'. Women who succeed in spite of all the difficulties may be denigrated as "quota-females". Under such circumstances, equal opportunity is still 'work in progress'.

As late as 1989, an old miner's prejudice struck female geology students. A student excursion of the University of Tübingen to the coal mine at Ibbenbüren had to be cancelled because the mining company, who worked the mine at that time, would not allow women underground. 
Table 4 Proportion of women earth scientists at British universities (1980-1998). Data from Bottomley (1992-1996), Ward (1992, 1997-2000).

\begin{tabular}{|c|c|c|c|c|c|c|c|c|c|c|c|c|c|c|c|}
\hline Status & year & 1985 & 1986 & 1987 & 1988 & 1989 & 1990 & 1991 & 1992 & 1993 & 1994 & 1995 & 1996 & 1997 & 1998 \\
\hline \multirow[t]{3}{*}{ first degrees } & total & 909 & 915 & 890 & 846 & 783 & 781 & 840 & 888 & 975 & 1117 & 1069 & n.d. & 1163 & 1068 \\
\hline & women & 195 & 209 & 194 & 194 & 183 & 193 & 216 & 240 & 276 & 304 & 335 & n.d. & 349 & 360 \\
\hline & percentage & 21.5 & 22.8 & 21.8 & 22.9 & 23.4 & 24.7 & 25.7 & 27.0 & 28.3 & 27.2 & 31.3 & n.d. & 30.0 & 33.7 \\
\hline \multirow[t]{3}{*}{ masters } & total & n.d. & n.d. & n.d. & n.d. & n.d. & 259 & 291 & 359 & 360 & 379 & 87 & n.d. & 270 & 272 \\
\hline & women & n.d. & n.d. & n.d. & n.d. & n.d. & 36 & 60 & 76 & 73 & 75 & 17 & n.d. & 71 & 103 \\
\hline & percentage & n.d. & n.d. & n.d. & n.d. & n.d. & 13.9 & 20.6 & 21.2 & 20.3 & 19.8 & 19.5 & n.d. & 26.3 & 37.9 \\
\hline \multirow[t]{3}{*}{ doctorates } & total & n.d. & $\mathrm{n}, \mathrm{d}$. & n.d. & n.d. & n.d. & 173 & 150 & 194 & 190 & 158 & 82 & n.d. & 109 & 144 \\
\hline & women & n.d. & n.d. & n.d. & n.d. & n.d. & 32 & 23 & 33 & 46 & 28 & 22 & n.d. & 24 & 38 \\
\hline & percentage & n.d. & n.d. & n.d. & n.d. & n.d. & 18.5 & 15.3 & 17.0 & 24.2 & $\$ 7.7$ & 26.8 & n.d. & 22.0 & 26.4 \\
\hline \multirow[t]{3}{*}{ staff } & total & 445 & 421 & 430 & 422 & 442 & 445 & n.d. & n.d. & n.d. & n.d. & n.d. & n.d. & n.d. & n.d. \\
\hline & women & 23 & 24 & 24 & 28 & 23 & 22 & n.d. & n.d. & n.d. & n.d. & n.d. & n.d. & n.d. & n.d. \\
\hline & percentage & 5.2 & 5.7 & 5.6 & 6.6 & 5.2 & 4.9 & n.d. & n.d. & n.d. & n.d. & n.d. & n.d. & n.d. & n.d. \\
\hline \multirow[t]{3}{*}{ staff newly employed } & total & n.d. & n.d. & n.d. & n.d. & n.d. & 43 & 44 & n.d. & n.d. & n.d. & 37 & n.d. & 42 & 53 \\
\hline & women & n.d. & n.d. & n.d. & n.d. & n.d. & 11 & 10 & n.d. & n.d. & n.d. & 8 & n.d. & 7 & 15 \\
\hline & percentage & n.d. & n.d. & n.d. & n.d. & n.d. & 25.6 & 22.7 & n.d. & n.d. & n.d. & 21.6 & n.d. & 16.7 & 28.3 \\
\hline
\end{tabular}

It is difficult to compare the German statistical figures with those available for the United Kingdom because of the different organisation of British universities and university degrees, and also because available official statistics do not give numbers for geology staff only. Therefore, it was necessary to draw on the Graduate Geological Scientists Survey compiled by Andrew Bottomley (years 1990 to 1994) and Bob Ward (years 1985 to 1990, 1995 to 1998) for the Geological Society of London, which gives representative data on the employment situation for geologists who made their degrees in the respective years (see Table 4, Figure 4).

The proportion of British female first degree holders $(33.7 \%$ in 1998 ) is slightly smaller but corresponds closely to the proportion of females among German geology students (35\% in 1998). However, for the doctoral candidates in 1998, the United Kingdom with 26.4\% women, ranked ahead of Germany with $22.4 \%$ females.

Nevertheless, between 1985 and 1990, women constituted only between 4.9 to $6.6 \%$ of academic staff in geology at universities of the United Kingdom (9.7 to $13.2 \%$ in Germany during the same period. However, if we consider permanent positions only, the German figures drop to $3.6 \%$ tenured women in 1998). In Britain, only one single woman, Janet Watson, was professor of geology between 1974 and her death in 1985 (Ward 1992). On the other hand, the proportion of women geologists in the British Geological Survey reached $16.5 \%$ in 1994 (Plant et al., 1994), a figure comparable to the situation at German universities, which had $16.2 \%$ of female geoscientists at that time.

In the years between 1983 and 1991, male geology graduates in Britain were more likely then their female colleagues to obtain jobs as geologists. In 1983, male graduates were more than twice as likely as female graduates to find employment as geoscientists. By 1991, this disparity between the sexes had nearly vanished. The observed disparity was basically due to the employment policies of the biggest recruiters of geologists in the United Kingdom, i.e. the oil companies and their contractors (an industry negligible in Germany), which offered between a third and half of the available jobs in those years. In 1984, men were over four and a half times more likely than women to find employment in this sector. In the same year, the British Equal Opportunity Commission lamented a widespread discrimination against women in the British oil industry. In other areas of geological employment, among others the universities, a survey of the years between 1983 and 1991 showed no significant differences in the fortunes of the two sexes (Ward, 1993). This can be seen also from the more recent data (see Table 4). Female geological staff at British universities is currently recruited in about the same proportion as it is available on the job market, leading to a steady increase of the proportion of women, which will eventually reach a level of equilibrium corresponding approximately to the proportion of women among geology students. A brief survey of web-pages of British geology departments showed that at present an average of about $14 \%$ of the geological staff are female. While thus the neglect of equal opportunity affairs during earlier decades still shows up in British statistics, the young female geoscientist of the end-1990s had an approximately equal chance to the academic job market; unlike their German colleagues, whose ever increasing numbers of qualified geologists did not lead to a corresponding increase of the proportion of female academic staff.

By the way: $19 \%$ of the participants of the 31 st International Geological Congress (Rio de Janeiro, 2000) were female (information courtesy 31 st IGC Scientific Committee).

\section{Acknowledgements}

This review article on the history of women geologists developed out of the official poster presentation of the Commission on the History of Geological Sciences (INHIGEO) at the IUGS stand at the 31st International Geological Congress in Rio de Janeiro in August 2000. I like to thank INHIGEO for the honour and the trust they have bestowed upon me in inviting me to prepare this exhibition.

I am deeply indebted to David Oldroyd (University of New South Wales/Australia, INHIGEO Secretary General) and Hugh Torrens (University of Keele/UK, Past-President INHIGEO) for helpful discussion and a considerable improvement of the English of the initial poster and of this paper. Further, I like to thank Beryl Hamilton (UK) and Katharina von Salis (Zurich) for much information on the topic of women geologists in the United Kingdom and in Switzerland. I am greatly indebted to the staff of the Statistisches Bundesamt (Federal Republic of Germany), Richard Howarth (Uni- 
versity College London) and Martin Scheuplein (Munich) for providing me with the statistical data. The work was partly financed by the Deutsche Forschungsgemeinschaft.

\section{References}

Adams, F.D., 1938, The Birth and Development of the Geological Sciences: Toronto, General Publishing Company, Ltd.

Agricola, G., 1556, De Re Metallica: Basel.

Alic, Margaret, 1986, Hypatia's Heritage: London, The Women's Press Ltd.

Benett, E., 1831, A Catalogue of the Organic Remains of the County of Wiltshire: Warminster, J.L. Vardy.

Bolt, B., 1987, 50 Years of Studies on the Inner Core: Eos, v. 68, no. 6, pp. $73,80-81$.

Bottomley, A., 1992, Graduate geological scientists survey 1990: Geoscientist, v. 2, no. 2, pp. 17-19.

Bottomley, A. 1993, Graduate geological scientists survey 1991: Geoscientist, v. 3, no. 6, pp. 24-25.

Bottomley, A. 1995, Graduate geological scientists survey 1992: Geoscientist, v. 5, no. 1, pp. 28-30.

Bottomley, A. 1995, Graduate geological scientists survey 1993: Geoscientist, v. 5, no. 6 , pp. $28-30$.

Bottomley, A. 1996, Graduate geological scientists survey 1994: Geoscientist, v. 6, no. 6, pp. 17-19.

Bundesministerium für Frauen und Jugend, 1993, 75 Jahre Frauenwahlrecht: Bonn.

Costas, I., 1997, Der Zugang von Frauen zu akademischen Karrieren - Ein internationaler Überblick, in Häntzschel, H., and Bußmann, H., 1997, Bedrohlich gescheit - Ein Jahrhundert Frauen und Wissenschaft in Bayern: München, C.H.Beck, pp. 15-34.

Creese, M. R. S., 1996, Maria Ogilvie Gordon (1864-1939): Earth Sciences History, v. 15 , pp. 68-75.

Creese, M.R.S., and Creese, Th.M., 1994, British women who contributed to research in the geological sciences in the nineteenth century: British Journal for the History of Science, v. 27, pp. 23-54.

Engelhardt, W., and Hölder, H., 1977, Mineralogie, Geologie und Paläontologie an der Universität Tübingen von den Anfängen bis zur Gegenwart: Contubernium, Beiträge zur Geschichte der Eberhard-KarlsUniversität Tübingen, v. 20, Tübingen, J.C.B. Mohr.

Faul, H., and Faul, C., 1983, It began with a stone. A history of geology from the stone age to the age of plate tectonics: New York, John Wiley \& Sons.

Gates, B.T., 1998, Kindred Nature. Victorian and Edwardian Women Embrace the Living World: Chicago, The University of Chicago Press.

Gobet, M., 1769, Les Anciens Minéralogistes de la France, 2 vols., Paris.

Göpel, M.L., 1986, Frauenalltag durch die Jahrhunderte: Ismaning, München.

Gordon, E.O., 1894, The Life and Correspondence of William Buckland, D.D., F.R.S., Sometime Dean of Westminster, Twice President of the Geological Society, and First President of the British Association: London, John Murray.

Graham, M., 1824, Journal of a residence in Chile, during the year 1822. And a voyage from Chile to Brazil in 1823: London, John Murray.

Grubitzsch, H., 1992, Kampf für mehr Rechte und mehr Freiheit - Frauen im Zeitalter der Revolutionen 1750-1850, in: Kuhn, A., 1992, Die Chronik der Frauen: Dortmund, Chronik-Verlag.

Häntzschel, H., and Bußmann, H., 1997, Bedrohlich gescheit - Ein Jahrhundert Frauen und Wissenschaft in Bayern: München, C.H.Beck.

Herzenberg, C.L., 1986, Women Scientists from Antiquity to the Present: An Index: West Cornwall, CT: Locust Hill Press.

Hofer, H., 1969, In memoriam Tilly Edinger: Morphologisches Jahrbuch, v. 113, pp. 303-317.

James, E.T., James, J.W., and Boyer, P.S., eds., 1971, Notable American Women, 1607-1950: A Biographical Dictionary: Cambridge, MA: Belknap Press of Harvard University Press.

Junginger, G., ed., 1991, Maria Gräfin von Linden - Erinnerungen der ersten Tübinger Studentin: Tübingen, Attempto.

Kölbl-Ebert, M., 1997 a, Mary Buckland née Morland 1797-1857: Earth Science History, v. 16, no. 2, pp. 33-38.

Kölbl-Ebert, M., 1997 b, Charlotte Murchison née Hugonin 1788-1869: Earth Science History, v. 16, no. 2, pp. 39-43.

Kölbl-Ebert, M., 1998, Hildegard von Bingen (1098-1179?): http://www.iaag.geo.uni-muenchen.de/sammlung/Hildegard.html

Kölbl-Ebert, M., 1999, Observing Orogeny - Maria Graham's Account of the Earthquake in Chile in 1822: Episodes, v. 22, no. 1, pp. 1-5.

Kölbl-Ebert, M., 2001. The Cardinal, the Witch and the Truth - The Strange Posthumous Life of Alchemist and Mining Engineer Martine de Bert- ereau: Universidade de Aveiro \& International Commission on the History of Geological Sciences (INHIGEO), INHIGEO Meeting - Portugal 2001, "Geological Resources and History", Programme and Abstracts, 24th, June - 1st, July /2001, Lisboa - Aveiro.

Kölbl-Ebert, M., British Geology in the Early 19th Century - A Conglomerate with a Female Matrix: Earth Sciences History [forthcoming].

Kuhn, A., ed., 1992, Die Chronik der Frauen: Dortmund: Chronik-Verlag.

Lang, W.D., 1950, More about Mary Anning including a newly-found letter: Proceedings of the Dorset Natural History and Archaeological Society, v. 71 , pp. $184-188$

LeGrand, H.E., 2000, The Plate tectonic Revolution 30 Years on: Retrospect and Prospects: Session 27-3, 31st Int. Geol. Congress, http://wwwrohan.sdsu.edu/ 3gleep6/speakers.html.

Loeblich, H.T., 1993, Reminiscence of Scientific Careers - Helen Tappan Loeblich and Alfred R. Loeblich, Jr: Earth Scientist, Fall 1993 Issue, pp. $10-11$.

Lyell, K.M., ed., 1881, Life, Letters and Journals of Sir Charles Lyell: 2 vols., London, John Murray.

Meister, M., 1997, Über die Anfänge des Frauenstudiums in Bayern, in Häntzschel, H., and Bußmann, H.: Bedrohlich gescheit - Ein Jahrhundert Frauen und Wissenschaft in Bayern: München, C.H.Beck, pp. 35-56.

Nagler-Springmann, S., 1995, Aschenputtel an Reißbrett und Reagenzglas Naturwissenschaftlerinnen als "Reservearmee" der deutschen Wirtschaft und Wissenschaft (1933-45) in Michel, R., ed., 1995, 21. Kongreß von Frauen in Naturwissenschaft und Technik, 25.-28. Mai 1995, Karlsruhe, Dokumentation: Darmstadt, FiT e.V.

Ogilvie, M.B., 1986, Women in Science. Antiquity through the Nineteenth Century: Cambridge, Masachusetts, MIT Press.

Plant, J.A., Hackett, D., and Taylor, B.J., 1994, The role of women in the British Geological Survey: Geology Today, July-August 1994, pp. 151156.

Rickards, R.B., 1999, A Century of Graptolite Research in Cambridge: The Geological Curator, v. 7, no. 2, pp. 71-76.

Rietschel, S., ed., 1985, Vom Naturalienkabinett zum Naturkundemuseum 1785-1985. Geschichte der Landessammlungen für Naturkunde: Karlsruhe, Landessammlungen für Naturkunde.

Rossiter, M.W., 1982, Women Scientists in America. Struggles and Strategies to 1940: Baltimore, The Johns Hopkins University Press

Rupp, E., 1978, Der Beginn des Frauenstudiums an der Universität Tübingen: Werkschriften des Universitätsarchivs Tübingen, Reihe 1: Heft 4.

Schiebinger, L., 1999, Has Feminism Changed Science?: Harvard University Press.

Scrutton, C., 1999, Dorothy Hill 1907-1997: Geoscientist, v. 9, pp. 24-25.

Sinclair, G.W., 1966, Memorial to Alice E. Wilson (1881-1964): Bulletin of the Geological Society of America, v. 77, pp. 215-218.

Somerville, M., ed. 1873, Personal Recollections, from Early Life to Old Age, of Mary Somerville. With Selections from her Correspondence: London, John Murray.

Spamer, Earle E., Bogan, Arthur E., and Torrens, Hugh S., 1989, Recovery of the Etheldred Benett Collection of Fossils Mostly from Jurassic-Cretaceous Strata of Wiltshire, England, Analysis of the Taxonomic Nomenclature of Benett (1831), and Notes and Figures of Type Specimens Contained in the Collection: Proceedings of the Academy of Natural Sciences of Philadelphia, v. 141, pp. 115-180.

Taylor, Michael A., and Torrens, Hugh S., 1987, Saleswoman to a New Science: Mary Anning and the Fossil Fish Squaloraja from the Lias of Lyme Regis: Proceedings of the Dorset Natural History and Archaeological Society, v. 108, pp. 135-148.

Torrens, Hugh S., 1985, Women in Geology, 2 - Etheldred Benett: Open Earth, v. 21, pp. 12-13.

Torrens, Hugh S., 1995, Mary Anning (1799-1847) of Lyme; 'the greatest fossilist the world ever knew': British Journal for the History of Science, v. 28, pp 257-84.

Torrens, Hugh S., Benamy, Elana, Daeschler, Edward B., Spamer, Earle E., and Bogan, Arthur E., 2000, Etheldred Benett of Wiltshire, England, the first lady geologist - Her fossil collection in the Academy of Natural Sciences of Philadelphia, and the rediscovery of 'lost' specimens of Jurassic Trigoniidae (Mollusca: Bivalvia) with their soft anatomy preserved: Proceedings of the Academy of Natural Sciences of Philadelphia, v. 150, pp. $59-123$.

Thackery., W.M., 1847, Vanity Fair: Wordsworth Classics, 1992.

Trunko, L., 1985, Vom fürstlichen Naturalienkabinett zum modernen Naturkundemuseum. Kurze Chronik der Landessammlungen für Naturkunde: in Rietschel, S., ed., 1985, Vom Naturalienkabinett zum Naturkundemuseum 1785-1985. Geschichte der Landessammlungen für Naturkunde: Karlsruhe, Landessammlungen für Naturkunde. 
Ward, B., 1992, Women and geology at UK universities: 1985-1990: Geology Today, September-October 1992, pp. 185-192.

Ward, B., 1993, Geological jobs for the boys? Statistics of the Representation of Women in Geology: Geoscientist, v. 3, no. 6, pp. 27-29.

Ward, B., 1997, Graduate geological scientists survey 1995: Geoscientist, v. 7 , no. 11 , pp. $20-23$.

Ward, B., 1999, Graduate geological scientists survey 1997: Geoscientist, v. 9, no. 4, pp. 4-10.

Ward, B., 2000, Graduate geological scientists survey 1998: Geoscientist, v. 10, no. 11, pp. 4-7.

Weitzenhoffer, K., 1987, The Education of Mary Somerville: Sky and Telescope, v. 73, pp. 138-139.

Wissenschaftsrat, 1998, Empfehlungen zur Chancengleichheit von Frauen in Wissenschaft und Forschung: Drs. 3534/98, Mainz (15.5.1998), http://www.wrat.de/drucksachen/drs3534-98/3534-98.htm

Xia, X., 1990, Luella Miner and her text book of geology (1910) in China: Abstracts, 15th International Symposium of the International Commission on the History of Geological Sciences (INHIGEO), Beijing.
Dr. Martina Kölbl-Ebert received her degrees in geology from the University of Tübingen. After working at the Museum of Natural History in Karlsruhe and at GEOMAR (Kiel), she is now a geological curator at the geological collection of the state of Bavaria, Germany. Her principal research interests are history of geosciences, and geochemistry of lamprophyres. She teaches museum education and volcanology at the University of Munich.

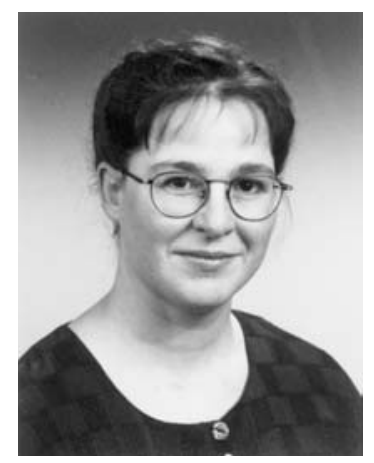

\title{
THE CAMPANIAN-MAASTRICHTIAN STAGE BOUNDARY CHARACTERISATION AND CORRELATION \\ FROM TERCIS-LES-BAINS (LANDES, SW FRANCE) TO EUROPE AND OTHER CONTINENTS
}

\author{
IUGS Special Publication (Monograph) Series 36 \\ Edited by G.S. Odin \\ Dépt Géologie Sedimentaire, 4, Place Jussieu, Case 119A, tour 16, 4e etage, F75252, \\ Paris Cedex 05, France
}

Included in series: Developments in Palaeontology and Stratigraphy, 19

The Phanerozoic calendar of the history of the earth is composed of fundamental units called stages. A priority of the International Commission on Stratigraphy is to redefine these stages using a modern approach. This work presents a unique solution to the previously debated and diversified locations of the Campanian-Maastrichtian boundary, providing a precise correlation using the most accepted known time markers. The Campanian and the Maastrichtian are the last two stages of the Cretaceous System.

This volume includes a large amount of previously unpublished stratigraphical data. With the use of uncertainty margins for observations, established by comparison of results obtained by various experts using different approaches for the same stratigraphical tool, a new approach to stratigraphical information was employed. While most of the data have been taken from the recently rediscovered geological site at Tercis, France, data from other sections around the world have been considered. The section studied at Tercis is the best stratigraphical record on Earth for the period of several million years across the Campanian-Maastrichtian boundary.

\section{Ordering information:}

\section{ELSEVIER, 2001}

Hardbound, 910 pages

ISBN: 0-444-50647-0

Price: NLG 295 (EUR 133.87) USD 145.50

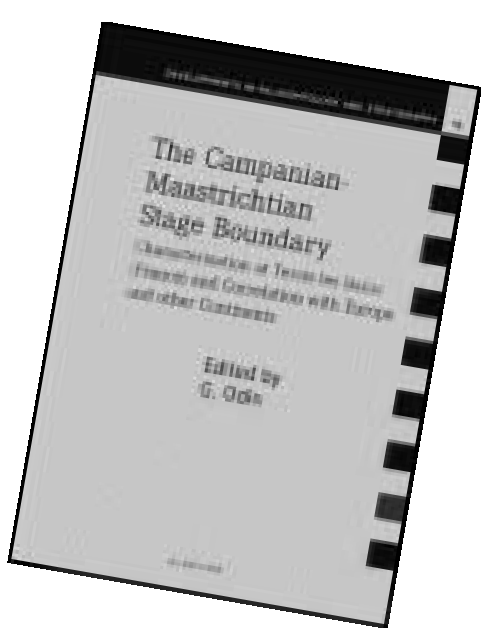

